УДК 378.22(045)

DOI: https://doi.org/10.51209/platform.1.3.2021.26-45

\author{
Олександр Вікторович IВАХНО, \\ Київська муніципальна академія \\ естрадного та циркового мистецтв, \\ Київ, Україна, \\ e-mail: o.ivahno@kmaecm.edu.ua, \\ ORCID: 0000-0001-6525-3947
}

\title{
СИСТЕМНІ ЗМІНИ В ПІДГОТОВЦ СТУДЕНТІВ ОСВІТНЬОЇ ПРОГРАМИ «РЕЖИСУРА» ТА ЇХ НАСЛІДКИ
}

Анотація. В Україні вже понад десять років запроваджується освітня реформа. Метою будь-якої реформи $\epsilon$ докорінна зміна всіх усталених боків суспільного життя, в даному випадку - навчального процесу в системі підготовки студентів-режисерів. Шлях, який відкриває студентам освітня реформа, - наполеглива самостійна робота. Найцінніше, що отримували студент раніше, - це методологічні засади роботи 3 цехами. Режисер був ключовою фігурою, саме він ніс відповідальність за цей напрям роботи. Реальність «психологічного театру» була основою учбового процесу як для акторів, так і для режисерів. Світ змінився, і виховна функція сценічного мистецтва набула нової ваги. Без підготовчої роботи не дозволялось ні акторам, ні режисерам працювати з обраними текстами, драматургічним матеріалом. Студентів готували до того, що сценічне мистецтво пов'язане з виробництвом, адже в театрі існують художня частина i виробнича. Перші чотири семестри навчання були цілком присвячені вивченню художніх особливостей сценічного мистецтва. На період навчання в театральній школі реальність «психологічного театру» ставала основою учбового процесу. Керівник режисерського курсу передавав учням свій досвід. Режисер - це індивідуальний феномен: неможливо прогнозувати, як швидко той чи інший студент засвоїть методологічні засади фаху і зможе працювати 
самостійно. У сучасні ВИШі приходять талановиті молоді люди, але без життєвого досвіду, необхідного для професії режисера. Тільки в Києві чотири заклади випускають режисерів. На жаль, лише невелика частка випускників буде спроможна стати режисерами. Основною метою статті є акцентувати увагу на проблемах сучасної освітньої реформи в галузі творчих спеціальностей, передусім - у підготовці режисерів. Проаналізовані головні актуальні проблеми сучасної системи підготовки режисерів, зроблений компаративний аналіз минулої та сучасної систем освіти.

Ключові слова: театр, режисура, акторська майстерність, ЗВО, освітня реформа

Вступ. В Україні вже понад десяток років запроваджується освітня реформа. Метою будь-якої реформи $є$ «докорінна зміна всіх усталених боків суспільного життя», в даному випадку - навчального процесу в системі підготовки студентів-режисерів. Шлях, який відкриває студентам освітня реформа, - наполеглива самостійна робота. Стара система підготовки «режисерських кадрів» зводилась здебільшого до формули, яку пропонував керівник курсу, а саме: «Роби як я». Найцінніше, що отримували студенти, - це методологічні засади роботи 3 цехами. Студентів готували до того, що сценічне мистецтво пов'язане 3 виробництвом, адже в театрі існують художня частина і виробнича. Перші чотири семестри навчання були цілком присвячені вивченню художніх особливостей сценічного мистецтва. На період навчання в театральній школі реальність «психологічного театру» ставала основою освітнього процесу. Керівник режисерського курсу передавав учням свій досвід. Досвід, який допомагав йому працювати в «театральновидовищних підприємствах» ще за умов радянської дійсності.

Постановка проблеми. Реальність «психологічного театру» була основою учбового процесу як для акторів, так і для режисерів. Курси були «змішаними» - акторськорежисерськими. Це давало змогу режисерам мати постійну режисерську практику, не бігаючи в пошуках виконавців, а 
акторам - навчатися працювати 3 різними режисерами. Особливу увагу в навчальному процесі приділяли вивченню автора. Весь навчальний процес, як у акторів, так і в режисерів, будувався навколо оригінальних авторських текстів. Автора вивчали, аналізували його твори. Без цієї підготовчої роботи не дозволялось ні акторам, ні режисерам працювати $з$ обраними текстами, драматургічним матеріалом.

Аналіз останніх досліджень і публікацій. Переважна кількість досліджень із проблем режисури, акторської майстерності, як i підготовки студентів зазначених спеціалізацій, створювалася також за часів СРСР (праці Є. Вахтангова, В. Мейєрхольда, К. Станіславського, лекції 3 режисури А. Тарковського), на сьогодні якісної літератури з цих питань не так багато, а праці з проблем освітнього процесу в цій царині швидко втрачають актуальність. Необхідно пригадати, що за радянських часів ВИШі, які готували режисерів, були ідеологічно спрямованими. Режисери були «на передовій ідеологічної боротьби». На думку радянських ідеологів, режисер мав бути «інженером людських душ». У радянські часи в творчій спільноті Києва був популярним жарт про Інститут театрального мистецтва ім. I. К. Карпенка-Карого, який прозвали «театральним гуртком при Кафедрі марксизмуленінізму». Жорстокий жарт, проте, він точно відображав акценти, які розставляла держава в підготовці майбутніх майстрів сцени. Тому сучасна література має зовсім інше ідеологічне забарвлення $[1 ; 3 ; 6-7 ; 10-11]$. До вітчизняних фахівців, які знаються на актуальних питаннях режисури та проблем підготовки кадрів у цій галузі, можна віднести Г. Веселовську [4-5], Г. Липківську [13-16], Г. Погребняк [1719], i H.

Мета статті - актуалізувати проблему підготовки кадрів у галузі режисури в умовах сьогоднішніх реалій.

Виклад основного матеріалу. Основна функція сценічного мистецтва, з точки зору радянських ідеологів, виховна. Режисер був ключовою фігурою, саме він ніс відповідальність за цей «напрям роботи». Світ змінився. Друзі 
стали ворогами, вороги - друзями, і виховна функція сценічного мистецтва набула нової ваги. Мистецтво, подобається це чи не подобається самим митцям, поза політикою бути не може. Наведу лише один історичний приклад. Коли фашистська Німеччина, на початку II Світової війни, увійшла на територію Польщі, перше, що зробили фашисти, - знищіли пам'ятники Ф. Шопену. Здавалося б, до чого тут музикант? Відповідь проста в народу не повинно бути національних авторитетів, тоді його легко підкорити.

Ступаючи на мистецький шлях, необхідно завжди пам'ятати - ми працюємо для людей, заради їх самих. Найбільша втрата, яку зазнала система підготовки режисерів, можливість здійснення дипломних проектів на сценах професійних театрів. Це означає відсутність можливості перевірити себе на професійній сцені, апробувати на практиці здобуті знання та навички, відчути дихання незаангажованої глядацької аудиторії, прочитати рецензії театральних критиків на свою виставу і переконатись у тому, що ти дійсно щось уже вмієш, що призводить до неочікуваних наслідків. Студентирежисери склали іспити, отримали високі бали, дипломи, почали працювати самостійно і... почалися метаморфози. Режисер «ставить самого себе» і складається враження, що для самого себе. Коли студент навчається, цю «хворобу» викладачу нескладно помітити. Під час навчання, починаючи працювати 3 авторськими текстами, драматургією, студенти-режисери, за виключенням тих, хто вже має акторську освіту, «підминають» драматургічний матеріал під себе: авторські «пропоновані обставини» підміняють режисерськими «пропонованими обставинами». Внаслідок такої підміни від автора іноді залишається лише назва твору. Таке «режисерське бачення» настільки заразне, що викорінити його дає можливість лише ще більш яскраве бачення. I тоді яскравіше бачення змінює ставлення режисера до можливостей сценічної реалізації драматургії.

Коли виникає більш яскраве бачення? Воно виникає у студента тоді, коли вдається переконати його, зазирнути в 
реальність, запропоновану автором твору. Таке звернення до автора, до першооснови, потребує від режисера певної жертви. Коли режисер $\epsilon$ ще студентом, він змушений коритись «примхам» викладачів, на «вільних хлібах» така необхідність зникає. Усе, що студент-режисер не міг дозволити собі, навчаючись у ЗВО, він дозволяє собі, ставши дипломованим фахівцем: виносити на сцену бачення, прийоми, «трактування», геть не пов'язані з авторськими. Режисер усе, що носив «у собі, коханому» всі роки навчання, «тягне» на сцену. «Сцена витримає все!». Зрозуміло, що ця сентенція, здебільшого, стосується режисерів-початківців, проте відомі режисери також страждають цією хворобою. Наприклад, А. Жолдак у кожній своїй виставі використовує одні й ті самі прийоми. Р. Стуруа в «Річарді III» В. Шекспіра і «Кавказькому крейдовому колі» Б. Брехта теж застосував одні й ті самі прийоми. М. Баранов у кожному своєму естрадному чи цирковому шоу теж використовує одні й ті самі прийоми. Прикладів вистачає. Виникає питання: «Чому так?». Відповідь, на мій погляд, на поверхні: ці прийоми подобаються самим режисерам i, час від часу, приносять успіх. Добре, коли цей успіх цілком заслужений.

3 початківцями ця ситуація виглядає не завжди оптимістично. Одна успішна робота $\epsilon-$ непогано. А далі чомусь часто не складається. Особливо це помітно на прикладі саме майбутніх режисерів. Дипломні роботи у студентів-режисерів виходять досить пристойними: їх «ведуть» викладачі. А цілком самостійні спроби, з використанням знайдених під час навчання прийомів впливу на глядацьку аудиторію, успіху не приносять. Чому? Риторичне питання. Режисер взяв до роботи іншого автора, і цей інший $є$ абсолютно інакшим. Знайдене раніше просто вже не працює. Звідси випливає, що або треба шукати драматургів, авторів зі схожими творчими засобами, подібною художньою мовою, або шукати інші прийоми втілення режисерського задуму.

Пошук нових художніх, театральних прийомів виразності, коли «режисер ставить самого себе», можливий 
лише 3 набуттям режисером власного життєвого досвіду і за підтримки розвиненої інтуїції. Згодом ми повернемось до теми відсутності власного життєвого досвіду у сучасних абітурієнтів, які мріють стати режисерами. Але збереження себе у професії вимагає від режисера-початківця успішних робіт уже просто зараз. Який вихід? Вихід, звичайно, там, де і вхід - кожен викладач режисури розповідає своїм студентам, що основою сценічної творчості є драматургія, і до творчості драматурга необхідно ставитись із усією повагою, наводить приклади майстрів старої школи, для я яких автор - це все, адже ставили автора. К.С. Станіславський, наприклад, себе режисером не вважав. Кожен викладач дає аналіз драматургічного матеріалу, розповідаючи про те, що саме аналіз $є$ запорукою успіху режисерських робіт. Питання: «Чому ж тоді режисери “забувають” цю настанову?»

Пітер Брук, даючи класифікацію режисерів, визначав три їх типи. Перший - режисер, що «абсолютно довіряє актору», «вони самі розберуться, головне - актору не заважати». Другий тип - режисер, який, як складається враження, «сам не знає, чого хоче». Він знає тільки те, що «має бути успіх». Такий режисер - «біда творчого колективу». Третій тип - режисер, який точно знає, чого він хоче. Такий режисер не боїться «рутинної роботи» - підготовчого періоду, приходить до актора тоді, коли «фільм готовий, лишилось його тільки зняти».

Режисер, що «довірився» актору, «ставити себе» не може. В основу співпраці з акторами режисер мусить поставити автора (він заручник ситуації) - так навчені актори. Актор у створенні образу йде від автора, аналізує драматургічний матеріал по подіях, визначає мету персонажа, вихідну подію, «зерно» образу. В запропонованих обставинах його цікавить місце дії, час дії (епоха, соціально-економічна формація, віросповідання, популярні філософські погляди відповідної епохи, побут, мода, чинники, які створюють емоційне тло, на якому відбуваються події). Актора цікавить, що про його персонажа говорить автор, що говорять про нього інші персонажі. Зібравши цю інформацію, він розробляє біографію 
персонажа. I, виходячи 3 усіх цих обставин, підходить до створення образу. Виконавши підготовчу роботу, актор, дійсно практично без допомоги режисера, може «розібратись», що виносити на сцену, а що - ні.

Режисер, який тримає в голові «успіх», довіряє тільки самому собі, своєму суб'єктивному розумінню, що буде мати успіх, а що - ні. Такий режисер «ставить самого себе», де в хід ідуть засоби, які, на його думку, змусять глядача не спати після побаченого, говорити зі знайомими про це, дискутувати, сперечатись. А якщо виникне скандал... Скандал це прекрасна реклама. На виставі обов'язково буде аншлаг. Аншлаг - це «успіх». У режисера, який «ставить самого себе», завжди $€$ одна-дві успішні роботи. Це непогано. Питання в іншому: за скільки років творчої діяльності?

Серед режисерів, які «ставили самих себе» і мали успіх, були видатні особистості. Так працювали Є. Гротовський, Л. Курбас, В. Мейєрхольд. Цих режисерів об'єднує одна спільна особливість - вони були освіченими людьми. Крім того, в них була жага до нового, до ще не баченого. Щоб так працювати, необхідно мати або хорошу інтуїцію, бути освіченою людиною. Про режисерів із розвиненою інтуїцією К.С. Станіславський говорив, що їм вчитись не треба - за них усе робить інтуїція. Про освічених, розмірковуючи про право режисера на трактування драматургічного матеріалу, сказав Г.О. Товстоногов: «...необхідно це право заслужити»...

Боюсь виглядати необ'єктивним, але прикладів сучасної геніальної інтуїтивної режисури, на жаль, навести не можу. Риторичним $є$ питання про освітній рівень абсолютної більшості сучасної режисерської молоді. Наприклад, наприкінці 2000-х рр. у КНУКІМ студентів-акторів, що не могли впоратися 3 навчанням за спеціалізацією, не відраховували, а переводили на режисуру. Режисер, який точно знає, чого хоче, іде від автора, від драматургічного матеріалу. Перше, на що звертає увагу такий режисер, - це актуальність драматургії. Можна зробити, 3 художньої точки зору, геніальну виставу, а зал буде порожнім. Такий режисер завжди пам'ятає, що він працює для глядача. 
Якщо драматургічний матеріал дійсно є актуальним, тоді він бере його до роботи. Починається підготовчий період: аналіз, експлікація. «Фільм готовий...» Вистава готова - лишилось іiі тільки поставити. 3 таким режисером приємно працювати творчому колективу. У режисерів, які проводять підготовчий період до початку роботи з актором, провалів, як правило, не буває.

Чому молоді режисери обирають саме «другий тип режисера»? Вся «заковика» в підготовчому періоді. Підготовчий період вимагає від режисера повного занурення в обставини часу, на тлі яких відбуваються події у драматургії, вивчення творчого шляху автора, історії сценічного втілення обраного драматургічного матеріалу. Цю роботу необхідно виконати. Режисери про це знають зі шкільних років: цьому їх вчать викладачі. На цю роботу необхідно витратити певну кількість часу заради «отримання права на трактування твору». На практиці творча молодь після складання іспитів у навчальних закладах кладе диплом на заздалегідь заготовлене місце і поруч iз ним, здається, залишає набуті в навчальному закладі знання. Так робить абсолютна більшість випускників творчих ВИШів. I у відповідь на запитання: «Чому не зробив?» ми чуємо відмовки. Вони не нові, але виконавці - найсучасніші. Головні відмовки «новаторів» звучать приблизно так: «Сучасна режисура має шукати нові форми, а школа веде нас перевіреним шляхом. Це вже нікому не потрібно. Подивіться, наприклад, як працює Роберт Уілсон!». А як працює Уілсон? Спочатку знаходить пластичний малюнок епізоду, ролі, а потім накладає на цей малюнок текст. Адже так працював i видатний український режисер Л. Курбас. У його театрі були аншлаги, а в основі його вистав залишався автор. Або: «Драматургія - це лише привід для роботи творчої лабораторії. В основі вистави мусить бути яскравий, оригінальний малюнок, трюк, номер. Саме за цим глядач приходить на вистави». I «Після Мейєрхольда можна все!»

Цю тезу теж нескладно заперечити. Так уже робив саме В. Мейєрхольд. Саме це відкриття трансформував у «Парад 
атракціонів» учень Мейєрхольда С. М. Ейзенштейн. У театрі у Мейєрхольда дійсно були аншлаги, проте, в основі його вистав все одно була драматургія, автор. $Є$ відмовки не такі потужні, проте їх щирість не залишає шансу на байдужість, наприклад: «Я так бачу». Режисер, як автор вистави, концерту, шоу, номеру, зобов'язаний мати своє бачення, яке вони і мають. Або: «Мені чомусь захотілось так зробити». Коли чуєш подібні зізнання, просто не розумієш, чим тут можна зарадити. До речі, в нові «новаторські» проекти охоче йдуть молоді актори. Чому в такі проекти неохоче йдуть досвідчені актори? Дуже гарна відмовка багатьох режисерів: «У мене брак часу». До речі, В. Мєйєрхольд готував свого «Ревізора» за твором М. В. Гоголя, дванадцять років, і це йому не заважало працювати над іншими виставами: проводити підготовчі періоди і ставити, ставити, ставити. Що казати, чому не зробили «рутинну роботу», ми вже навчились, знаємо. А от як залишитись у професії? Щоб режисеру залишитись у професії, потрібен успіх, касовий збір, де одна помилка знижує його шанси до нуля. Який вихід? Взяти актуальну тему... А що таке актуальна тема, актуальність? Радянська режисерська школа вимагала від студента відповідального ставлення до вибору автора та драматургії. На курсі С.В. Данченка, коли йому приносили обрані для курсових робіт твори, перше, про що питав Сергій Володимирович, актуальність твору. Не дозволялось брати в роботу драматургічний матеріал без обгрунтування вибору твору.

Актуальність - важливість, значимість чого-небудь на сьогодні, сучасність, злободенність, це властивість інформації, відомостей, норм, яка може бути втрачена з часом, із появою свіжої, сучаснішої інформації. Актуальність може втрачатись поступово, частинами, або в певних випадках - разово i повністю.

Театрознавець Ю. Бобошко (1925-1988 рр.) наводив приклад зміни актуальності твору на п’єсі В. Шекспіра «Ромео та Джульєтта». У 1961 р. радянські війська в Берліні збудували за ніч стіну 3 бетону. Східний та західний сектори відповідальності цих військ було таким чином розділено. 
Розділили столицю Німеччини, розділили німецькі родини, розділили закоханих. За одну ніч п'єса Шекспіра набула популярності в західній Свропі, в театрах аншлаги. Шалений успіх.

Завдяки актуальності має успіх і проект «95-й квартал». Цей приклад сценічного досвіду естрадних виконавців розмовного жанру підтверджує, що драматургія обов'язково має бути актуальною. Дійсно, на основі нової драматургії можна зробити щось небачене. Якщо драматургія буде актуальною, глядач прийде. До речі, невідома драматургія одразу відсікає частину критиків. Щодо критеріїв оцінювання вистави, циркового, естрадного номеру, то серед деяких режисерів існує думка, що оцінювати режисерську роботу будуть за тими законами, які запропонував сам режисер.

Г.К. Липківська у своєму дослідженні «Світ у дзеркалі драми» наводить критерій, за яким «визначалась» і зараз «визначається» майстерність режисера: «...театр XX - початку XXI ст. настільки розширив свої рамки, що перетворює будь-які тексти, первісно геть не призначені для постановки на кону (за мірило майстерності режисера тут традиційно слугує «телефонна книга» - мовляв, вправний режисер іiі поставить)» [16].

Хочеться вірити, що впродовж років навчання режисери сумлінно відвідували лекції про художню цілісність вистави, а цей, не новий, погляд є спробою приховати свої помилки. Якщо не мати підготовчий період до зустрічі з акторами, а проводити «дієвий аналіз драматургії», усе одно необхідно знайти образ вистави: визначити стиль, у якому драматургія розкриється як найкраще, знайти режисерський прийом подачі драматургічного матеріалу, визначитись із принципом мізансценування, знайти відповідний спосіб існування акторів у сценічному просторі в залежності від жанру драматургії та обраного режисером, постановчою групою стилю. I нарешті, необхідно придумати головну сцену вистави - фінал. Він дає глядачу відповіді на питання, які в нього виникли під час перегляду вистави. Глядач спостерігає за розгортанням подій у виставі заради відповіді на 
питання: «Хто правий?». Для глядача $\epsilon$ важливим визначити правильну ідею. Якщо це відбудеться - глядач відчує приємний «післясмак», тоді він знову буде шукати зустрічі з майстрами сцени.

Вибір інструментів впливу на глядача - право кожного режисера, його особиста відповідальність. Будь-який режисер прагне успіху. Без цієї умови неможливо донести до глядача головну думку, ідею, заради якої і робиться вистава. Студенти мистецьких ВИШів часто задають питання: «Ну як?». Не буває жодної репетиції без цього питання. Воно в погляді, жесті, позі. Насправді, за цим коротким «як» - безліч питань, але головне, що хвилює митця, - «чи вдалось зачепити серце глядача». Якщо вдалось - це перемога. I все одно лишаються питання: «Що сподобалось?» «Що сподобалось найбільше?» Питання, питання, питання. Їх студенти задають усім, хто бачив їх роботи, але найбільше прислухаються до творчих авторитетів.

Театральний режисер i педагог П.І. Ільченко про авторитетів для студента говорить так: «У навчальному процесі немає другорядного, він багатоплановий - усі навчаються у всіх: студенти вчаться у майстра курсу, студенти вчаться у студентів, викладач вчиться у студентів, усі разом навчаються у глядача. В навчальному процесі всі взаємозалежні. Випадає одна ланка - i відбувається збій в учбовій роботі».

Режисер та педагог Л.А. Олійник казав, що актори, режисери ніби пливуть у човні проти течії бурхливої річки, де зупинки бути не може - течія знесе човен назад. Важливий кожен член команди човна, особистий внесок кожного. Кожен член команди має бути максимально відповідальним за свою роботу в колективі. Тільки згуртована команда досягає поставленої мети.

Освітня реформа дає нам чотири години на тиждень на опанування майстерністю актора у ЗВО, шість годин на режисуру (приклад КМАЕЦМ, але є заклади, де кількість годин, що виділені на профільні дисципліни ще менша). Цього достатньо? Ні. Годинами, відведеними на режисуру, викладач змушений перекривати годинний голод у викладанні 
майстерності актора і шукати додаткові можливості зустрічей із студентами задля практичних занять. Питання: «Як за таких умов створити команду?» Відповідь напрошується сама собою: «А ніяк». За десять годин на тиждень поєднати теорію 3 практикою неможливо.

Чому виникає потреба в додаткових заняттях? Режисер це, так би мовити, індивідуальний феномен: неможливо прогнозувати, як швидко той чи інший студент засвоїть методологічні засади фаху і зможе працювати самостійно.

Неможливо не сказати про нову систему відбору абітурієнтів на вступних іспитах. У ВИШі приходять абітурієнти, що склали ЗНО, в основному це діти, які не мають жодного уявлення про професію режисера. Вони талановиті, але в цих дітей немає життєвого досвіду, необхідного для професії режисера. ЗВО змушені їх приймати, відповідно до нових правил відбору та прийому. Сучасна система набору студентів у спеціалізовані навчальні заклади на програми з режисури, м'яко кажучи, мусить бути іншою. Зараз виходить, що в двадцять один рік випускник уже за фахом є режисером. Тільки в Києві чотири заклади випускають таких режисерів. Ясно, що з часом iз цих випускників лише хтось, за певних умов, спроможний буде стати режисером.

Висновки. У досвідчених викладачів є таке прислів'я: «Кого набереш - того і випустиш». Станом на сьогодні освітня реформа можливо i працю» у ВИШах, де основний фах пов'язаний із точними науками, в мистецьких 3 ВО вона лише шкодить. Стару систему, яка приносила художній результат, зруйнували. Нова поки що не працює. I чи запрацює? Система, яка обмежує спілкування учня $з$ викладачем, не $\epsilon$ «ноу-хау» освітньої реформи, яку запроваджують. У Мілані, наприклад, режисерів музичного театру готують, вичитуючи їм курс лекцій iз теорії режисури і все: ані індивідуальних, ані практичних, ані факультативних занять немає. Все, що стосується практичної підготовки майбутніх режисерів, лягає на плечі самих студентів: «Шукайте гранти». А чи є у наших студентів такі можливості? 


\section{Література}

1. Аль Д. Основы драматургии. Ленинград: ЛГИК им. Н. К. Крупской, 1988. 46 с.

2. Басин Е. Психологические основы системы

Станиславского. Москва: Гуманитарий, 1990. 136 с.

3. Буров А. Режиссура и педагогика. Москва: Советская Россия, 1987. 160 с.

4. Веселовська Г. Перша жінка-український театральний режисер Ірина Дєєва. Сучасне мистецтво. 2019 Вип. 15. Cc. 69-76.

5. Веселовська Г. Простір жінки в українському авангардному театрі. Сучасне мистецтво. 2018. Вип. 154. Cc. 107-114.

6. Горчаков Н. Режиссерские уроки Станиславского. Москва: Искусство, 1951. 567 с.

7. Горчаков Н. Режиссерские уроки Вахтангова. Москва: Искусство, 1957. 240 с.

8. Ершов П. Режиссура как практическая психология. Взаимодействие людей в жизни и на сцене. Режиссура как построение зрелища. Москва: Мир искусства, 2010. 408 с.

9. Зайцев В. Режисура естради та масових видовищ. Навч. посіб. Київ: Дакор, 2003. 304 с.

10. Захава Б. Мастерство актера и режиссера Москва: Просвещение, 1973. 201 с.

11. Захава Б., Міронов К. Робота режисера. Київ: Мистецтво, 1937.95 с.

12. Конович Н. Подготовка к написанию курсовой работы обучающихся по специальности 52.05.02 «Режиссура театра», специализации «Режиссёр эстрады». Метод. реком. СанктПетербург: СПбГИК, 2019.

13. Липківська Г. Проблеми сучасної театральної критики. Сучасні проблеми художньої освіти в Україні. 2009. Вип. 5. Cc. $155-158$.

14. Липківська Г. Деякі аспекти модернізації викладання історії театру у мистецьких 3ВО. Арт-платформа. 2020. Вип. 1. Cc. 94-108. 
15. Липківська Г. Сучасний український театр крізь призму фестивалю-премії «ГРА-GRA» (2018-2020 рр.). Арт-платформа. 2020. Вип. 2. Сс. 34-56.

16. Липківська Г. Світ у дзеркалі драми. Київ: Кий, 2007. $356 \mathrm{c}$.

17. Погребняк Г. Авторський кінематограф у культурному просторі другої половини XX - початку XXI століття. Київ: НАКККіМ, 2020. 448 c.

18. Погребняк Г. Авторський кінематограф крізь призму мистецької особистості. Київ: НАКККіМ, 2012. 128 с.

19. Погребняк Г. Авторська режисура в екранному та сценічному мистецтві. Науковий вісник Київського національного університету театру, кіно і телебачення імені I.К. Карпенка-Карого. 2017. Вип. 20. Сс. 115-122.

20. Скрипина Н. Подготовка режиссеров театрализованных представлений и праздников в вузах культуры и искусств к социально-культурной деятельности. Автореф. .. дис. канд. пед. н. Челябинск, 2009. 25 с.

21. Скрипина Н. Исследование готовности студентов режиссерских специальностей к профессиональной деятельности и сущность понятия «профессионализм режиссера театрализованных представлений и праздников». Вестник Таджикского гос. национального университета. Душанбе: Ситпо, 2007. Сс. 184-193.

22. Скрипина Н. Осуществление интеграционных взаимосвязей учебных предметов в организации педагогического процесса режиссерских специальностей вузов культуры и искусств. Вестник ЧГАКИ. Челябинск, 2007. No1(11). Cc. 51-57.

23. Скрипина Н. Формирование профессионализма у студентов режиссерских специализаций средствами прикладной хореографии.Вестник ин-та пед. исслед. ЧГАКИ. 2003. № 1. Сc.113-118.

24. Скрипина Н. Формирование умений реализации художественного замысла у студентов - будущих режиссеров на примере обучения прикладной хореографии. Художественное 
образование в XXI веке: проблемы, поиски, перспективы: Межвуз. сб. научн. трудов. 2 вып. Урал. гос.пед. ун-т. Екатеринбург, 2008. Сс. 142-151.

25. Тарковский А. Уроки режиссуры. Москва: ВИППК, 1993. $92 \mathrm{c}$.

\section{Александр Викторович ИВАХНО,}

Киевская муниципальная академия эстрадного и циркового искусств,

Киев, Украина, e-mail: o.ivahno@kmaecm.edu.ua, ORCID: 0000-0001-6525-3947

\section{СИСТЕМНЫЕ ИЗМЕНЕНИЯ В ПОДГОТОВКЕ СТУДЕНТОВ ОБРАЗОВАТЕЛЬНОЙ ПРОГРАММЫ «РЕЖИССУРА» И ИХ ПОСЛЕДСТВИЯ}

Аннотация. В Украине уже более десяти лет вводится образовательная реформа. Целью любой реформы является «коренное изменение всех устоявшихся сторон общественной жизни», в данном случае - учебного процесса в системе подготовки студентов-режиссеров. Путь, который открывает студентам образовательная реформа, - упорная самостоятельная работа. Самое ценное, что получали студенты раньше, - это методологические основы работы с цехами. Режиссер был ключевой фигурой, именно он нес ответственность за это направление работы. Реальность «психологического театра» была основой учебного процесса как для актеров, так и для режиссеров. Мир изменился, и воспитательная функция сценического искусства приобрела новый вес. Без подготовительной работы не разрешалось ни актерам, ни режиссерам работать с выбранными текстами, драматургическим материалом. Студентов готовили к тому, что сценическое искусство связано с производством, ведь в театре существуют художественная часть и производственная. Первые четыре семестра обучения были целиком посвящены изучению 
художественных особенностей сценического искусства. На период обучения в театральной школе реальность «психологического театра» становилась основой учебного процесса. Руководитель режиссерского курса передавал ученикам свой опыт. Режиссер - это индивидуальный феномен: невозможно прогнозировать, как быстро тот или иной студент усвоит методологические основы профессии и сможет работать самостоятельно. В современные ВУЗы приходят талантливые молодые люди, но без жизненного опыта, необходимого для профессии режиссера. Только в Киеве четыре заведения выпускают режиссеров. К сожалению, лишь небольшая доля выпускников будет способна стать режиссерами. Основной целью статьи является акцентирование внимание на проблемах современной образовательной реформы в области творческих специальностей, прежде всего - в подготовке режиссеров. Проанализированы главные актуальные проблемы современной системы подготовки режиссеров, сделан компаративный анализ прошлой и современной систем образования.

Ключевые слова: театр, режиссура, актерское мастерство, ЗВО, образовательная реформа

Olexander V. IVAHNO,

Kyiv Municipal Academy of Circus and Performing Arts, Kyiv, Ukraine, e-mail: o.ivahno@kmaecm.edu.ua, ORCID: 0000-0001-6525-3947

\title{
SYSTEMIC CHANGES IN THE PREPARATION OF STUDENTS OF THE EDUCATIONAL PROGRAM "DIRECTING" AND ITS CONSEQUENCES
}

\begin{abstract}
Educational reform has been undergoing in Ukraine for more than a decade. The goal of any reform is to "radically change all established aspects of public life", in this case, the educational process in the system of training students-directors.
\end{abstract}


The path that the educational reform opens up for students is hard independent work. The most valuable thing that students received earlier was the methodological foundations of working with workshops. The director was a key figure, and he was responsible for this area of work. The reality of "psychological theater" was the basis of the educational process for both actors and directors. The world has changed, and the educational function of Performing Arts has acquired a new weight. Without preparatory work, neither actors nor directors were allowed to work with selected texts or dramatic material. Students were trained to the fact that stage art is connected with production, because in the theater there is an artistic part and a production part. The first four semesters of study were entirely devoted to the study of the artistic features of Performing Arts. During the period of studying at the theater school, the reality of 'psychological theater' became the basis of the educational process. The head of the directing course passed on his experience to the students. A director is an individual phenomenon: it is impossible to predict how quickly a particular student will learn the methodological foundations of the specialty and be able to work independently. Talented young people come to modern universities, but without the life experience, necessary for the profession of director. Only in Kyiv, four institutions prepare specialists-directors. Unfortunately, only a small proportion of graduates will be able to become directors really. The main purpose of the article is to focus on the problems of modern educational reform in the field of creative specialties, primarily in the training of directors. The main actual problems of the modern system of training directors are analyzed, and a comparative analysis of the past and modern education systems is made.

Key words: theater, directing, acting, institution of high education, educational reform 


\section{References}

1. Al', D. (1988). Osnovy dramaturgii [Basics of drama]. Leningrad: LGIK im. N. K. Krupskoy [in Russian].

2. Basin, YE. (1990). Psikhologicheskiye osnovy sistemy Stanislavskogo [Psychological foundations of the Stanislavsky system]. Moscow: Gumanitariy [in Russian].

3. Burov, A. (1987). Rezhissura i pedagogika [Directing and pedagogy]. Moscow: Sovetskaya Rossiya [in Russian].

4. Veselovs'ka, H. (2019). Persha zhinka-ukrayins'kyy teatral'nyy rezhyser Iryna Dyeyeva [The first woman-Ukrainian theater director Irina Deeva]. Suchasne mystetstvo, 15, 69-76 [in Ukrainian].

5. Veselovs'ka. H. (2018). Prostir zhinky v ukrayins'komu avanhardnomu teatri [Women's space in the Ukrainian avant-garde theater]. Suchasne mystetstvo, 154, 107-11 [in Ukrainian].

6. Gorchakov, N. (1951). Rezhisserskiye uroki Stanislavskogo [Directing lessons of Stanislavsky]. Moscow: Iskusstvo [in Russian].

7. Gorchakov, N. (1957). Rezhisserskiye uroki Vakhtangova [Directing lessons of Vakhtangov]. Moscow: Iskusstvo [in Russian].

8. Yershov, P. (2010). Rezhissura kak prakticheskaya psikhologiya. Vzaimodeystviye lyudey $\mathrm{V}$ zhizni i na stsene. Rezhissura kak postroyeniye zrelishcha [Directing as a practical psychology. The interaction of people in life and on stage. Directing as the construction of a spectacle]. Moscow: Mir iskusstva [in Russian].

9. Zaytsev, V. (2003). Rezhysura estrady ta masovykh vydovyshch [Directing pop and mass spectacles. Teaching]: Navch. posib. Kyiv: Dakor [in Ukrainian].

10. Zakhava, B. (1973). Masterstvo aktera i rezhissera [Mastery of Actor and Director]. Moscow: Prosveshcheniye [in Russian].

11. Zakhava, B., Mironov, K. (1937). Robota rezhysera [he work of the director]. Kyiv: Mystetstvo [in Ukrainian].

12. Konovich, N. (2019). Podgotovka k napisaniyu kursovoy raboty obuchayushchikhsya po spetsial'nosti 52.05.02 "Rezhissura teatra", spetsializatsii "Rezhissor estrady" [Preparation for writing a term paper for students in the specialty 52.05.02 "Theater Directing", 
specialization "Stage Director"]. Metod. rekom. Sanct-Petersburg: SPbGIK [in Russian].

13. Lypkivs'ka, H. (2009). Problemy suchasnoyi teatral'noyi krytyky [Problems of modern theater criticism]. Suchasni problemy khudozhn'oyi osvity v Ukrayini], 5, 155-158 [in Ukrainian].

14. Lypkivs'ka, H. (2020). Deyaki aspekty modernizatsiyi vykladannya istoriyi teatru u mystets'kykh ZVO [Some aspects of modernization of teaching the history of theater in artistic intitutiones of high education]. Art-platforma, 1, 94-108 [in Ukrainian].

15. Lypkivs'ka, H. (2020). Suchasnyy ukrayins'kyy teatr kriz' pryzmu festyvalyu-premiyi «HRA-GRA» (2018-2020 rr.) [Modern Ukrainian theater through the prism of the HRA-GRA AwardFestival]. Art-platforma, 2, 34-56 [in Russian].

16. Lypkivs'ka, H. (2007). Svit u dzerkali dramy [The world in the mirror of drama]. Kyiv: Kiy [in Ukrainian].

17. Pohrebnyak, H. (2020). Avtors'kyy kinematohraf u kul'turnomu prostori druhoyi polovyny XX - pochatku XXI stolittya [Author's cinema in the cultural space of the second half of the XX beginning of the XXI century]. Kyiv: NAKKKiM [in Ukrainian].

18. Pohrebnyak, H. (2012). Avtors'kyy kinematohraf kriz' pryzmu mystets'koyi osobystosti [Author's cinema through the prism of artistic personality]. Kyiv: NAKKKiM [in Ukrainian].

19. Pohrebnyak, H. (2017). Avtors'ka rezhysura v ekrannomu ta stsenichnomu mystetstvi [Author's direction in screen and stage art]. Naukovyy visnyk Kyyivs'koho natsional'noho universytetu teatru, kino i telebachennya imeni I. K. Karpenka-Karoho, 20, 115-122 [in Ukrainian].

20. Skripina, N. (2009). Podgotovka rezhisserov teatralizovannykh predstavleniy i prazdnikov v vuzakh kul'tury i iskusstv k sotsial'no-kul'turnoy deyatel'nosti [Preparation of directors of theatrical performances and holidays in universities of culture and arts for social and cultural activities]. Avtoref. .. dis. kand. ped. n. Chelyabinsk, 25 p. [in Russian].

21. Skripina, N. (2007). Issledovaniye gotovnosti studentov rezhisserskikh spetsial'nostey $\mathrm{k}$ professional'noy deyatel'nosti i sushchnost' ponyatiya 'professionalizm rezhissera teatralizovannykh 
predstavleniy i prazdnikov' [Research of the readiness of students of directing specialties for professional activity and the essence of the concept of "professionalism of the director of theatrical performances and holidays']. Vestnik Tadzhikskogo gos. natsional'nogo universiteta. Dushanbe: Sitpo, 184-193 [in Russian].

22. Skripina, N. (2007). Osushchestvleniye integratsionnykh vzaimosvyazey uchebnykh predmetov $\mathrm{v}$ organizatsii pedagogicheskogo protsessa rezhisserskikh spetsial'nostey vuzov kul'tury i iskusstv [Implementation of integration relationships of academic subjects in the organization of the pedagogical process of directing specialties of universities of culture and arts]. Vestnik CHGAKI. Chelyabinsk, (11), 51-57 [in Russian].

23. Skripina, N. (2003). Formirovaniye professionalizma u studentov rezhisserskikh spetsializatsiy sredstvami prikladnoy khoreografii [Formation of professionalism among students of directing specializations by means of applied choreography]. Vestnik in-ta ped. issled. CHGAKI, 1, 113-118 [in Russian].

24. Skripina, N. (2008). Formirovaniye umeniy realizatsii khudozhestvennogo zamysla u studentov - budushchikh rezhisserov na primere obucheniya prikladnoy khoreografii. Khudozhestvennoye obrazovaniye v XXI veke: problemy, poiski, perspektivy [Formation of skills for the implementation of artistic design among students future directors on the example of teaching applied choreography. Art education in the XXI century: problems, searches, prospects]: Mezhvuz. sb. nauchn. trudov, 2. Ural. gos.ped. un-t. Yekaterinburg, 142-151 [in Russian].

25. Tarkovskiy, A. (1993). Uroki rezhissury [Directing lessons]. Moscow: VYPUSK [in Russian]. 